Байло О. В., кандидат юридичних наук, доцент кафбедри иивільно-правових дисииплін Одеського національного університету імені I. I. Мечникова

\title{
ОКРЕМІ ПИТАННЯ ПРИТЯГНЕННЯ РОБОТОДАВЦЯ ДО ВІДПОВІДАЛЬНОСТІ ЗА ЗАТРИМКУ РОЗРАХУНКУ ПІД ЧАС ЗВІЛЬНЕННЯ
}

\begin{abstract}
Анотація. У статті на основі вивчення судової практики розкриваються особливості застосування інституту матеріальної відповідальності роботодавця за затримку розрахунку під час звільнення. Особливу увагу приділено проблемам встановлення вини роботодавця. Зіставлено положення національного законодавства, Трудового кодексу Російської Федерації та проекту Трудового кодексу України.
\end{abstract}

Ключові слова: матеріальна відповідальність, роботодавець, затримка розрахунку під час звільнення, вина роботодавця, грошова компенсація.

Постановка проблеми. Реформування національного законодавства у сфері праці актуалізує практичні проблеми звільнення працівника, саме як певної сукупності дій з боку сторін трудового договору. Наприклад, на думку Ю.С. Тихоновича, «недотримання правил звільнення, порушення трудового законодавства під час розірвання трудових відносин викликають наслідки як для працівників, так і для роботодавців після припинення трудових відносин. Саме тому звільнення як розрив трудових відносин треба зарахувати до соціальної проблеми, актуалізація якої пов'язана з механізмами реалізації прав роботодавців і працівників у процесі звільнення, які свого часу не можливі за відсутності основного засобу впливу на суспільні відносини - правового регулювання державою» [1, с. 408].

Аналіз останніх досліджень і публікацій. Вивченню питання припинення трудового договору та матеріальної відповідальності роботодавця присвятили наукові роботи такі науковці, як Н.Б. Болотіна, В.С. Венедіктов, К.М. Гусов, В.В. Жернаков, М.І. Іншин, І.Я. Кисельов, Є.В. Краснов, А.М. Лушніков, М.В. Лушнікова, С.П. Маврін, К.Ю. Мельник, Д.В. Могила, А.Ю. Пашерстник, П.Д. Пилипенко, О.М. Потопахіна, С.М. Прилипко, В.І. Прокопенко, Я.В. Свічкарьова, Я.В. Сімутіна, К.Л. Томашевський, Є.Б. Хохлов, Н.М. Хуторян, Г.І. Чанишева, В.І. Щербіна, О.С. Щукін, О.М. Ярошенко та інші.

Метою статті $\epsilon$ вивчення судової практики розгляду справ щодо затримки розрахунку під час звільнення та виявлення актуальних проблем притягнення роботодавця до матеріальної відповідальності.

Виклад основного матеріалу дослідження. Г.І. Чанишева на підставі аналізу чинного законодавства й судової практики виділяє «затримку розрахунку під час звільнення як окремий випадок матеріальної відповідальності роботодавця перед працівником у трудових правовідносинах. Усі випадки матеріальної відповідальності роботодавця за всієї різноманітності, на думку вченого, можуть бути класифіковані на декілька груп залежно від характеру порушених прав працівника або відповідних їм обов'язків роботодавця. Перша група - матеріальна відповідальність роботодавця за порушення права працівника на працю (зокрема, затримка розрахунку під час звільнення). Друга група - матеріальна відповідальність роботодавця за заподіяння шкоди майну працівника (порча, знищення або пропажа особистих речей під час роботи; завдання іншої майнової шкоди майну працівника). Третя група - матеріальна відповідальність роботодавця за порушення обов'язку видачі працівнику документів про роботу і заробітну плату» [2, с. 227].

Відповідно до ч. 1 ст. 47 Кодексу законів про працю України (далі - КЗПП України) власник або уповноважений ним орган зобов'язаний у день звільнення видати працівникові належно оформлену трудову книжку і провести 3 ним розрахунок у строки, зазначені в ст. 116 цього Кодексу [3, ст. 47]. А згідно 3 ч. 1 ст. 116 КЗпП України під час звільнення працівника виплата всіх сум, що належать йому від підприємства, установи, організації, провадиться в день звільнення [3, ст. 116].

Згідно з ч. 1 ст. 117 КЗпП України в разі невиплати з вини власника або уповноваженого ним органу належних звільненому працівникові сум у строки, зазначені в ст. 116 цього Кодексу, за відсутності спору про їхній розмір підприємство, установа, організація повинні виплатити працівникові його середній заробіток за весь час затримки по день фактичного розрахунку [3, ст. 117].

Отже, якщо роботодавець не провів розрахунку із працівником із власної вини у зазначені строки, то такі дії можна розглядати підставою для відповідальності, передбаченої ст. 117 КЗПП України. Після ухвалення судового рішення про стягнення заборгованості із заробітної плати роботодавець не звільняється від відповідальності, передбаченої ст. 117 КЗпП України, а саме виплати середнього заробітку за час затримки розрахунку під час звільнення, тобто за весь період невиплати роботодавцем належних працівникові під час звільнення сум.

Юридично важливим складником правопорушення норм трудового законодавства $€$ вина роботодавця, оскільки, за положеннями ст. 117 КЗпП України, обов' язковою умовою для покладення на підприємство відповідальності за невиплату належних працівникові сум під час звільнення є наявність вини підприємства. Проте на практиці виникають певні особливості встановлення вини роботодавця.

Згідно із ст. 4 КЗпП України «законодавство про працю складається 3 цього Кодексу та інших актів законодавства України, прийнятих відповідно до нього» [3, ст. 4]. Згідно 3 ч. 1 ст. 9 Цивільного кодексу України (далі - ЦК України) «положення цього Кодексу застосовуються до врегулювання, зокрема, трудових відносин, якщо вони не врегульовані іншими актами законодавства» [4, ст. 9]. 
Нині в регулюванні трудовим законодавством відносини 3 приводу відшкодування майнової та моральної шкоди є недосконалими. У зв'язку із цим на практиці використовуються положення цивільного законодавства, які можуть поширюватися на такі відносини.

Під час розгляду справи Судова палата в цивільних справах Верховного Суду України дійшла висновку, що вимоги про виплату компенсації у зв'язку з несвоєчасною виплатою належних працівникові сум, а також відшкодування моральної шкоди регулюються гл. 82 ЦК України та під час вирішення спірних питань застосуванню підлягають положення цивільного законодавства.

Водночас ст. 617 ЦК України передбачено, що особа, яка порушила зобов'язання, звільняється від відповідальності за порушення зобов' язання, якщо вона доведе, що це порушення сталося внаслідок випадку або непереборної сили [4, ст. 617]. У п. 1 ч. 1 ст. 263 ЦК України наведено ознаки непереборної сили як надзвичайної або невідворотної за даних умов події [4, ст. 263]. Отже, непереборною силою є надзвичайна або невідворотна зовнішня подія, що звільняє від відповідальності особу, яка порушила зобов'язання, за умови, що остання не могла іiі передбачити або передбачила, але не могла їі відвернути, і ця подія завдала збитків.

Частинами 1, 2 ст. 14-1 Закону України «Про торгово-промислові палати в Україні» передбачено таке: «Торгово-промислова палата України та уповноважені нею регіональні торгово-промислові палати засвідчують форс-мажорні обставини (обставини непереборної сили) та видають сертифікат про такі обставини протягом семи днів із дня звернення суб' єкта господарської діяльності за собівартістю. Сертифікат про форс-мажорні обставини (обставини непереборної сили) для суб'єктів малого підприємництва видається безкоштовно. Форс-мажорними обставинами (обставинами непереборної сили) є надзвичайні та невідворотні обставини, що об' єктивно унеможливлюють виконання зобов'язань, передбачених умовами договору (контракту, угоди тощо), обов'язків згідно із законодавчими та іншими нормативними актами, а саме: загроза війни, збройний конфлікт або серйозна загроза такого конфлікту, включаючи, але не обмежуючись ворожими атаками, блокадами, військовим ембарго, дії іноземного ворога, загальна військова мобілізація, військові дії, оголошена та неоголошена війна, дії суспільного ворога, збурення, акти тероризму, диверсіі, піратства, безлади тощо» [5].

Зазначений висновок відповідає правовій позиції Верховного Суду України, викладеній у постановах від 23 березня 2016 р. у № 6-364цс16 [6] та від 11 травня 2016 р. № 6-383ц16 [7].

Відповідно до ст. 233 КЗпП України «працівник може звернутися із заявою про вирішення трудового спору безпосередньо до районного, районного у місті, міського чи міськрайонного суду в тримісячний строк із дня, коли він дізнався або повинен був дізнатися про порушення свого права, а у справах про звільнення - у місячний строк із дня вручення копії наказу про звільнення або з дня видачі трудової книжки. У разі порушення законодавства про оплату праці працівник має право звернутися до суду з позовом про стягнення належної йому заробітної плати без обмеження будь-яким строком. Якщо місячний чи тримісячний строк пропущено без поважних причин, у позові може бути відмовлено з цих підстав» [3, ст. 233].
У правовому висновку, висловленому в постанові від 8 листопада 2017 р. у справі № 202/4914/16-ц, Верховний Суд України вказав, «що для звернення працівника до суду із заявою про вирішення трудового спору щодо стягнення середнього заробітку за весь час затримки по день фактичного розрахунку встановлено тримісячний строк, перебіг якого розпочинається 3 дня, коли звільнений працівник дізнався або повинен був дізнатися про те, що власник або уповноважений ним орган, з вини якого сталася затримка виплати всіх належних під час звільнення сум, фактично розрахувався з ним» [8].

Окрім того, відповідно до ч. 5 ст. 235 КЗпП України, «у разі затримки видачі трудової книжки з вини власника або уповноваженого ним органу працівникові виплачується середній заробіток за весь час вимушеного прогулу» [3, ст. 235].

Проте помилковим є застосування до роботодавця відповідальності у вигляді стягнення середнього заробітку, яка передбачена ст. ст. 117 та 235 КЗПП України, оскільки подвійне стягнення середнього заробітку не співмірне з правами працюючого працівника, який отримує одну заробітну плату.

У положеннях ст. ст. 117, 235 КЗПП України йдеться про відповідальність роботодавця у вигляді стягнення середнього заробітку за час одного й того ж прогулу працівника задля компенсації йому втрат від неотримання зарплати чи неможливості працевлаштування. Наприклад, у постанові Судової палати у цивільних справах Верховного Суду України від 18 січня 2017 р. у справі № 6-2912цс16: «Ураховуючи, що більш тривале порушення трудових прав позивачки викликане невидачею трудової книжки, тому колегія суддів Судової палати у цивільних справах Верховного Суду України вважає за необхідне застосувати до спірних правовідносин положення ст. 235 КЗпП України» [9].

Розрахунок належних звільненому працівникові сум здійснюється відповідно до Порядку обчислення середньої заробітної плати, який затверджено постановою Кабінету Міністрів України від 8 лютого 1995 р. № 100. Під час обчислення розміру середнього заробітку за весь час затримки по день фактичного розрахунку треба використовувати формулу, за якою обрахуванню підлягає період затримки за робочі дні з опертям на середньоденний заробіток, обчислений згідно з положеннями Порядку, якщо іншого непередбачено чинним законодавством (постанова Судової палати у цивільних справах Верховного Суду України від 1 березня 2017 р. у справі № 6-2807цс16) [10].

У разі непроведення розрахунку у зв'язку з виникненням спору про розмір належних до виплати сум вимоги про відповідальність за затримку розрахунку підлягають задоволенню в повному обсязі, якщо спір вирішено на користь позивача або такого висновку дійде суд, що розглядає справу.

У разі часткового задоволення позову працівника суд визначає розмір відшкодування за час затримки розрахунку з урахуванням спірної суми, на яку працівник мав право, частки, яку вона становила в заявлених вимогах, істотності цієї частки, порівняно із середнім заробітком та інші конкретні обставини справи. Сама по собі відсутність коштів у роботодавця не позбавляє його відповідальності.

Отже, суд має право зменшити розмір середнього заробітку, що має сплатити роботодавець працівникові за час затримки виплати з вини роботодавця, за таких умов: 1) наявність спору між працівником і роботодавцем із приводу розміру належних до виплати працівникові сум за трудовим договором на день звільнення; 2) виникнення спору між роботодавцем і працівником 
після того, як належні до виплати працівникові суми за трудовим договором у зв'язку з його звільненням повинні бути сплачені роботодавцем; 3) прийняття судом рішення щодо часткового задоволення вимог працівника про виплату належних йому під час звільнення сум у строки, визначені ст. 116 цього Кодексу [11].

Водночас за змістом п. 20 постанови Пленуму Верховного Суду України від 24 грудня 1999 р. № 13 «Про практику застосування судами законодавства про оплату праці», «у разі часткового задоволення позовних вимог працівника про стягнення середнього заробітку за час затримки розрахунку під час звільнення суд визначає розмір такого відшкодування з урахуванням розміру спірної суми, на яку працівник мав право, частки, яку вона становила в заявлених вимогах, істотності цієї частки, порівняно із середнім заробітком, та інші конкретні обставини справи» [12].

Застосування принципу співмірності під час визначення розміру відшкодування працівникові середнього заробітку за час затримки розрахунку під час звільнення тлумачиться як право суду, а не обов' язок (постанова Судової палати у цивільних справах Верховного Суду України від 13 березня 2017 р. у справі № 6-259цс17) [11].

Варто зазначити, що у зв'язку із порушенням вимог ст. 117 КЗПП України до юридичних і фізичних осіб-підприємців, які використовують найману працю, застосовують, окрім іншого, фінансові санкції, передбачені ст. 265 КЗпП України. Застосування таких фінансових санкцій не звільняє роботодавця від обов'язку виплати заборгованих працівнику сум. Відповідно до ст. 41 КУПАП, «порушення термінів виплати пенсій, стипендій, заробітної плати, виплата їх не в повному обсязі тягнуть за собою накладення штрафу на посадових осіб підприємств, установ і організацій незалежно від форми власності та громадян - суб'єктів підприємницької діяльності від тридцяти до ста неоподатковуваних мінімумів доходів громадян» [13].

Цікавим видається законодавчий досвід Російської Федерації щодо регулювання відповідальності роботодавця перед працівником. Наприклад, ст. 236 Трудового кодексу РФ визначено, що «у разі порушення роботодавцем встановленого терміну, відповідно, виплати заробітної плати, оплати відпустки, виплати під час звільнення та (або) інших виплат, що належать працівнику, роботодавець зобов'язаний виплатити їх зі сплатою відсотків (грошової компенсації) в розмірі не нижче однієї сто п'ятдесятої чинної ключової ставки центрального банку Російської Федерації від невиплачених у строк сум за кожний день затримки, починаючи 3 наступного дня після встановленого строку виплати по день фактичного розрахунку включно. За неповної виплати у встановлений термін заробітної плати та (або) інших виплат, що належать працівнику, розмір відсотків (грошової компенсації) обчислюється 3 фактично не виплачених у строк сум. Розмір виплачуваної працівнику грошової компенсації може бути підвищений колективним договором, локальним нормативним актом або трудовим договором. Обов'язок із виплати зазначеної грошової компенсації виникає незалежно від наявності вини роботодавця» [14, ст. 236]. Отже, у разі затримки розрахунку під час звільнення роботодавець у РФ сплачує грошову компенсацію безпосередньо працівнику, натомість в Україні винні дії роботодавця із затримки виплат під час звільнення тягнуть сплату безпосередньо самої заборгованої суми працівнику та фінансових санкцій, кошти від яких надходять до державного бюджету України.
Висновки. Чинним законодавством передбачена відповідальність за затримку розрахунку під час звільнення (ст. 117 КЗПП, ст. 265 КЗПП, ст. 41 КУПАП), проте заходів, передбачених законодавством, не досить для запобігання затримці розрахунку під час звільнення або добровільного виконання роботодавцями своїх обов'язків.

Аналіз наведених норм матеріального права дає підстави для висновку, що передбачений ч. 1 ст. 117 КЗПП України, - обов'язок роботодавця щодо виплати середнього заробітку за час затримки розрахунку під час звільнення настає за умови невиплати з його вини належних звільненому працівникові сум у строки, зазначені в ст. 116 КЗПП України, при цьому визначальними є такі юридично значимі обставини, як невиплата належних працівникові сум під час звільнення та факт проведення з ним остаточного розрахунку.

Вивчення судової практики свідчить про те, що наявна значна кількість судових справ щодо затримки розрахунку під час звільнення, яка демонструє недосконалість правового механізму впливу на роботодавця та запобігання таким випадкам. Отже, особливої актуальності набуває питання вдосконалення правового регулювання інституту відповідальності роботодавця перед працівником і дослідження законодавства інших держав у цій царині.

Треба зазначити, що проект Трудового кодексу України в питанні відповідальності роботодавця за затримку розрахунку 3 працівником, з яким припинено трудові відносини, не містить жодних нововведень. Вважаємо доцільним, крім виплати зазначених сум (суми заробітної плати, інших виплат), покласти на роботодавця обов'язок сплатити працівникові грошову компенсацію, розмір якої має бути встановлений законодавством у сфері праці.

Лimepamyра:
1. Тихонович Ю.С. Правовий механізм регулювання звільнення 3 ініціативи працівника. Актуальні проблеми держави та права. 2014. С. 408-413.

2. Чанишева Г.І. Відповідальність роботодавця за трудовим законодавством. Публічне право. 2016. № 2. С. 225-232.

3. Кодекс законів про працю: Закон УРСР від 10 грудня 1971 р. Відомості Верховної Ради. 1971. № 50. Ст. 375.

4. Цивільний кодекс України: Закон України від 16 січня 2003 р. № 435-15. URL: http://zakon2.rada.gov.ua/laws/show/435-15 (дата звернення: 15.11.2018).

5. Про торгово-промислові палати в Україні: Закон України від 2 грудня 1997 p. URL: http://zakon2.rada.gov.ua/laws/show/671/97$\% \mathrm{D} 0 \% 92 \% \mathrm{D} 0 \% \mathrm{~A} 0$ (дата звернення: 15.11.2018).

6. Постанова Верховного Суду України від 23 березня 2016 р. у справі № 6-364цс16. URL: http://reyestr.court.gov.ua/ Review/56786341 (дата звернення: 15.11.2018).

7. Постанова Верховного Суду України від 11 травня 2016 р. у справі № 6-383цс16. URL: http://reyestr.court.gov.ua/ Review/57787446 (дата звернення: 15.11.2018).

8. Постанова Верховного Суду України від 8 листопада 2017 р. у справі № 202/4914/16-ц.URL: http://reyestr.court.gov.ua/ Review/70229677 (дата звернення: 15.11.2018).

9. Постанова Верховного Суду України від 18 січня 2017 р. у справі № 6-2912цс16. URL: http://reyestr.court.gov.ua/Review/ 64344972 (дата звернення: 15.11.2018).

10. Постанова Верховного Суду України від 1 березня 2017 р. у справі № 6-2807цс16. URL: https://oda.court.gov.ua/ sud1590/pravovipoziciivsu/6-2807cs16 (дата звернення: 15.11.2018).

11. Постанова Верховного Суду України від 13 березня 2017 р. у справі № 6-259цс17. URL: https:/oda.court.gov.ua/ sud1590/pravovipoziciivsu/6-259cs17 (дата звернення: 14.11.2018). 
12. Постанова Верховного Суду України від 11 жовтня 2017 р. у справі № 6-1638цс17. URL: http://reyestr.court.gov.ua/ Review/69649885 (дата звернення: 15.11.2018).

13. Кодекс України про адміністративні правопорушення: Закон УРСР № 8073-Х від 7 грудня 1984 р. Відомості Верховної Ради Української РСР. 1984. Додаток до № 51. Ст. 1122.

14. Трудовой кодекс Российской Федерации: Закон РФ от 30 декабря 2001 г. № 197-Ф3 (ред. от 03.08.2018). URL: http://www.consultant.ru/ document/cons_doc_LAW_34683/ (дата звернення: 15.11.2018).

Байло Е. В. Отдельные вопросы привлечения работодателя к ответственности за задержку расчета при увольнении

Аннотация. В статье на основе изучения судебной практики раскрываются особенности применения института материальной ответственности работодателя за задержку расчета при увольнении. Особое внимание уделено проблемам установления вины работодателя. Сопо- ставлены положения национального законодательства, Трудового кодекса Российской Федерации и проекта Трудового кодекса Украины.

Ключевые слова: материальная ответственность, работодатель, задержка расчета при увольнении, вина работодателя, денежная компенсация.

Bailo O. Some issues of attracting the employer to responsibility for delay of calculation at the dismissal

Summary. In the article, based on the study of judicial practice, the peculiarities of the application of the employer's material liability institution for delaying the calculation on dismissal are disclosed. Particular attention is paid to problems of establishing the fault of the employer. The provisions of the national legislation, the Labor code of the Russian Federation and the draft Labor code of Ukraine are compared.

Key words: material responsibility, employer, delay in calculating with dismissal, employer's fault, monetary compensation. 